\title{
Policy lessons from comparing mortality from two global forces: international terrorism and tobacco George Thomson and Nick Wilson*
}

Address: Department of Public Health, Wellington School of Medicine and Health Sciences, University of Otago, PO Box 7343, Wellington South, New Zealand

Email: George Thomson - gthomson@wnmeds.ac.nz; Nick Wilson* - nwilson@actrix.gen.nz

* Corresponding author

Published: 15 December 2005

Globalization and Health 2005, I:18 doi:10.1/86/1744-8603-I-I8
Received: 23 August 2005

Accepted: I5 December 2005

This article is available from: http://www.globalizationandhealth.com/content/l/I/l8

(C) 2005 Thomson and Wilson; licensee BioMed Central Ltd.

This is an Open Access article distributed under the terms of the Creative Commons Attribution License (http://creativecommons.org/licenses/by/2.0), which permits unrestricted use, distribution, and reproduction in any medium, provided the original work is properly cited.

\begin{abstract}
Background: The aim of this study was to compare the mortality burdens from two global impacts on mortality: international terrorism and the major cause of preventable death in developed countries - tobacco use. We also sought to examine the similarities and differences between these two causes of mortality so as to better inform the policy responses directed at prevention.
\end{abstract}

Methods: Data on deaths from international terrorism were obtained from a US State Department database for 1994-2003. Estimates for tobacco-attributable deaths were based on Peto et al 2003. The countries were 37 developed and East European countries.

Results and discussion: The collective annualized mortality burden from tobacco was approximately 5700 times that of international terrorism. The ratio of annual tobacco to international terrorism deaths was lowest for the United States at 1700 times, followed by Russia at 12,900 times. The tobacco death burden in all these countries was equivalent to the impact of an II September type terrorist attack every 14 hours.

Different perceptions of risk may contribute to the relative lack of a policy response to tobacco mortality, despite its relatively greater scale. The lack is also despite tobacco control having a stronger evidence base for the prevention measures used.

Conclusion: This comparison highlights the way risk perception may determine different policy responses to global forces causing mortality. Nevertheless, the large mortality differential between international terrorism and tobacco use has policy implications for informing the rational use of resources to prevent premature death.

\section{Background}

International terrorism, or aspects of it, have been argued to be a reaction to globalization and/or to be aided by many of its features $[1,2]$. In the last twenty or more years, there has been a substantial focus on terrorism-related policies in many jurisdictions, particularly since the attacks of 11 September 2001 in the United States. This focus has included spending and legislation, and has included public health measures relating to bioterrorism protection $[3,4]$. The focus is understandable, considering the political significance of attacks by non-state organisations, and the economic and psychological effects on the 
Table I: Mortality burdens from tobacco and international terrorism in developed and East European countries

\begin{tabular}{|c|c|c|c|c|c|}
\hline Country & $\begin{array}{l}\text { Number of } \\
\text { international } \\
\text { terrorist attacks } \\
(1994-2003)\end{array}$ & $\begin{array}{c}\text { Number of } \\
\text { international } \\
\text { terrorism deaths } \\
(1994-2003)^{* *}\end{array}$ & $\begin{array}{c}\text { International } \\
\text { terrorism deaths } \\
\text { (per million } \\
\text { population per } \\
\text { year) }(1994-2003)\end{array}$ & $\begin{array}{c}\text { Total deaths } \\
\text { attributed to } \\
\text { tobacco in year } \\
2000 \text { (estimated by } \\
\text { Peto et al) }\end{array}$ & $\begin{array}{c}\text { Ratio of tobacco } \\
\text { deaths to } \\
\text { annualized } \\
\text { international } \\
\text { terrorism deaths }\end{array}$ \\
\hline \multicolumn{6}{|c|}{ Established market economies } \\
\hline Australia & 0 & 0 & 0 & 18,600 & - \\
\hline Austria & 0 & 0 & 0 & 8,900 & - \\
\hline Belgium & 0 & 0 & 0 & 18,600 & - \\
\hline Canada & 0 & 0 & 0 & 44,800 & - \\
\hline Denmark & 0 & 0 & 0 & 11,600 & - \\
\hline Finland & 0 & 0 & 0 & 5,200 & - \\
\hline France & 7 & 19 & 0.032 & 64,900 & 34,158 \\
\hline Germany & 2 & 3 & 0.004 & 111,100 & 370,333 \\
\hline Greece & 3 & 3 & 0.027 & 13,400 & 44,667 \\
\hline Ireland & 0 & 0 & 0 & 5,700 & - \\
\hline Italy & 0 & 0 & 0 & 80,700 & - \\
\hline Japan & 0 & 0 & 0 & 114,200 & - \\
\hline Netherlands & 1 & 6 & 0.037 & 25,700 & 42,833 \\
\hline New Zealand & 0 & 0 & 0 & 4,500 & - \\
\hline Norway & 0 & 0 & 0 & 5,600 & - \\
\hline Portugal & 0 & 0 & 0 & 8,400 & - \\
\hline Spain & 1 & 1 & 0.002 & 46,400 & 464,000 \\
\hline Sweden & 0 & 0 & 0 & 8,200 & - \\
\hline Switzerland & 1 & 1 & 0.014 & 6,800 & 68,000 \\
\hline United Kingdom & 3 & 32 & 0.054 & 114,000 & 35,625 \\
\hline United States & 2 & 2,970 & 1.020 & 514,000 & I,73। \\
\hline Subtotal & 20 & 3,035 & $0.35 \mathrm{I}$ & $1,231,300$ & 4,057 \\
\hline \multicolumn{6}{|c|}{ Former socialist economies of Europe* } \\
\hline Belarus & 0 & 0 & 0 & 18,000 & - \\
\hline Bulgaria & 0 & 0 & 0 & 11,200 & - \\
\hline Croatia & 0 & 0 & 0 & 8,000 & - \\
\hline Czech Republic & 0 & 0 & 0 & 17,900 & - \\
\hline Estonia & 0 & 0 & 0 & 2,700 & - \\
\hline Hungary & 0 & 0 & 0 & 28,700 & - \\
\hline Latvia & 0 & 0 & 0 & 4,100 & - \\
\hline Lithuania & 0 & 0 & 0 & 4,700 & - \\
\hline Macedonia & 0 & 0 & 0 & 2,000 & - \\
\hline Poland & 1 & 1 & 0.003 & 68,700 & 687,000 \\
\hline Romania & 0 & 0 & 0 & 31,900 & - \\
\hline Russia & 7 & 256 & 0.178 & 330,000 & $|2,89|$ \\
\hline Serbia \& Montenegro & 3 & 6 & 0.057 & 17,800 & 29,667 \\
\hline Slovakia & 0 & 0 & 0 & 8,100 & - \\
\hline Slovenia & 0 & 0 & 0 & 2,900 & - \\
\hline Ukraine & 0 & 0 & 0 & 99,100 & - \\
\hline Subtotal & II & 263 & 0.081 & 655,800 & 24,935 \\
\hline $\begin{array}{l}\text { Total (all selected } \\
\text { countries) }\end{array}$ & 31 & 3,298 & 0.278 & $1,887,100$ & 5,722 \\
\hline
\end{tabular}

* Excluding Albania, and Bosnia and Herzegovina for which tobacco-related mortality burdens were not available. Moldova was not included in the WHO report from which this grouping comes.

** Excluding the deaths of perpetrators. 
societies which may consider themselves attacked [5-7]. However, it is important for policy makers to know of the opportunity costs of the response to international terrorism, relative to addressing other causes of premature death, and to better understand how differences in risk perception influence policy making. Therefore, we contrasted the mortality impacts of international terrorism with another major cause of preventable death - tobacco use [8] (which is also exacerbated by globalization $[9,10])$. This work is part of a wider attempt to put international terrorism into a public health context $[11,12]$.

\section{Methods}

As part of a study to describe the epidemiology of international terrorism [11] we extracted data for 1994-2003 on international terrorist attacks involving any deaths among non-perpetrators from United States (US) Department of State reports. The definition of terrorism used by the Department is: 'Premeditated, politically motivated violence perpetrated against noncombatant targets by subnational groups or clandestine agents', with international terrorism meant as 'terrorism involving citizens or the territory of more than one country'. These data were supplemented with findings from more detailed published studies (see: [11]). Countries included were 21 'established market economy' countries and 16 'former socialist economies of Europe' (as per the classification in an international mortality study) [13]. These two groups of countries were selected because there was better quality data available for both terrorism and tobacco. From these data, an average annual mortality burden was calculated for each country.

Data on tobacco mortality was based on the updated estimates for the year 2000 by Peto et al [14]. This method involves country-specific rates of lung cancer mortality together with corresponding rates from the American Cancer Society's Cancer Prevention Study II to derive 'smoking impact ratios' by age and sex. The burden includes tobacco-related: respiratory diseases, vascular diseases and other tobacco-related cancers. This methodology has been shown to be a robust indicator of the accumulated hazards of smoking [15].

Rates were calculated using the most recent population data for each country from the World Health Organization website http://www.who.int/country/en/.

\section{Results}

For the selected countries collectively, the annual mortality burden from tobacco was approximately 5700 times that of the average annual mortality burden from international terrorism (Table 1). For 26 of the countries, there were no deaths from international terrorism. Within the other 11 countries, the ratio of annual tobacco to interna- tional terrorism deaths was lowest for the US at 1700 times, followed by Russia at 12,900 times.

The absolute annual burden from tobacco was highest for the US at 514,000 deaths per year in 2000 (Table 1). This is equivalent to the impact of an 11 September type terrorist attack every 2.1 days. For all of these 37 countries collectively, the tobacco mortality burden was equivalent to the impact of an 11 September type terrorist attack every 14 hours.

\section{Discussion}

Definitions of terrorism are highly contended [16-18]. Furthermore, we have identified some limitations with the US State Department dataset, including with the definition used [11]. Indeed, if a tighter definition of international terrorism was used, then this would substantially reduce the number of deaths categorised in this way (eg, relative to domestic terrorism or other types of homicide [11]). Therefore this analysis may over-represent the mortality burden from international terrorism to some degree.

In contrast, the tobacco mortality estimates may be underestimates of the true mortality burden. This is because the estimates by Peto et al ignore all deaths in those aged under 35 years (including neonatal deaths and deaths from sudden infant death syndrome attributable to smoking), and the methodology was one of 'conservative underestimation of tobacco hazards' [19]. More recent data also suggests that the long-term hazards of smoking on health are probably higher than previously thought [20]. Nevertheless, methodologies for assessing the tobacco-related mortality burden differ and for the US a more recent analysis [21] indicates a lower mortality burden attributable to tobacco (ie, 438,000 versus the 514,000 calculated by Peto et al and used in this analysis).

Despite these various limitations, the findings of this analysis suggest that the mortality burden from tobacco use is at present vastly greater than from international terrorism in all the selected countries studied. This is even the case for the US, which has suffered the worst mortality burden from international terrorism out of these countries in the last decade.

Why does tobacco mortality not receive a proportionate response? Some may find comparisons between 'catastrophic' and 'normal' deaths misplaced [22]. We recognise the subjectivity of risk perception $[23,24]$, and the tendencies of populations to: (i) overestimate risks stemming from visible, well publicised sudden violence with collective results, particularly where the cause is not well understood, compared to risks with results dispersed over place and time; and (ii) to overestimate risks from causes were there is little apparent control by the individual, 
compared to risks from causes which appear to many to be voluntarily undertaken [25-27].

This tendency may be exacerbated by disproportionate media coverage of certain causes of mortality which involve low risk at the individual level $[28,29]$. There is also the political problem of giving priority to long-term issues, compared to dealing with emotive immediate concerns $[30,31]$. However, we have also demonstrated elsewhere that even for another cause of mortality which results in visible, well publicised sudden death (road crashes), policymaking does not appear to take into account the disproportionate mortality burden, compared to that from international terrorism [12].

International terrorism and the harm from tobacco use have similarities, in that they both involve discrete perpetrators - international terrorist groups and the globalized tobacco industry - against which governments can take action. Also, many tobacco deaths globally are due to the actions of foreigners - policymakers and company officials in tobacco manufacturing and exporting countries. Both international terrorism and tobacco use can substantially harm national economies and the international economic fabric in many ways $[32,33]$. Similarly, both can have widespread impacts on the way society functions and on its institutions eg, terrorism on security arrangements, and tobacco via the tobacco industry on the functioning of political processes $[34,35]$. The costs from both are largely or totally preventable, and investment in longterm prevention for both, as opposed to containment, may not necessarily be mutually exclusive (eg, if military budgets are diverted to terrorism prevention).

Despite these similarities, there are substantive differences. One is that the tobacco industry, unlike terrorists, is generally described as 'a legal industry' ie, an industry taking part in legal activity. This is despite the fact that the deliberate sale of a highly addictive, commonly lethal substance, and the routine denial of some harms (eg, of secondhand smoke) may be considered reckless criminal behaviour under the laws of some countries [36]. This presumed 'legality' contributes to the societal acceptance and political strength of the tobacco industry in developed countries, relative to international terrorist groups.

Secondly, there is considerable evidence about the preventability of tobacco-related harm using current methods, and of their cost-effectiveness [37-40], compared to the high uncertainty about the effectiveness of particular measures to prevent international terrorism or its health impacts $[41,42]$. From a public health perspective, antiterrorism efforts tend to focus on immediate containment, rather than addressing the possible root causes of terrorism [43-46]. The cost-effectiveness of public health measures related to potential terrorism impacts has had little conclusive research $[47,48]$.

A further difference, as this analysis indicates, is the vastly different scale of the consequent mortality burdens. The policy implications of this include the relative extent, effectiveness and cost-effectiveness of the resources used to address the two problems [49-52]. A public health and evidence-based approach may suggest a greater relative emphasis on tobacco control both nationally and internationally. While public health budgeting will always have to take into account public concerns that are not based on the evidence of relative risks, we argue that such policy moves should be as rigorously examined, as is the budgeting for tobacco control. A further possible implication is to learn from the response to international terrorism, so as to inform the way that tobacco marketing can be reframed as a serious threat to the social and economic well-being of individual countries and to international social and economic development.

\section{Conclusion}

This analysis suggests a very large mortality differential between these two problems exacerbated by globalization, international terrorism and tobacco use. Different perceptions of risk may contribute to the relative lack of a policy response to tobacco mortality, despite its greater scale. The lack of an appropriate response is also despite tobacco control having a stronger evidence base for the prevention measures used. National and international policy makers need to consider these issues if they are to make more rational use of resources to prevent premature mortality.

\section{Competing interests}

Both authors have undertaken contract work for tobacco control-related non-government agencies, and NW has undertaken contract work in tobacco control for the New Zealand Ministry of Health.

\section{Authors' contributions}

Both authors contributed to the design of the study, the data collection and the drafting and final write up of the manuscript. NW undertook the data analysis.

\section{Acknowledgements}

We thank two anonymous reviewers for helpful comments on the draft. There were no funding sources for this study.

\section{References}

I. Cronin A: Behind the Curve: Globalization and International Terrorism. International Security 2002, 27:30-58.

2. Campbell K: Globalization's First War? The Washington Quarterly 2002, 25:7-14.

3. Frist $B$ : Public health and national security: the critical role of increased federal support. Health Affairs (Millwood) 2002, 21:117-130. 
4. Coignard B: Bioterrorism preparedness and response in European public health institutes. European Surveillance 200I, 6:159-166.

5. Galea S, Vlahov D, Resnick H, Ahern J, Susser E, Gold J, Bucuvalas M, Kilpatrick D: Trends of probable post-traumatic stress disorder in New York City after the September II terrorist attacks. American Journal of Epidemiology 2003, 158:5।4-524.

6. Dhooge LJ: A previously unimaginable risk potential: September II and the insurance industry. American Business Law Journal 2003, 40:687-780.

7. Fremont WP, Pataki C, Beresin EV: The impact of terrorism on children and adolescents: terror in the skies, terror on television. Child and Adolescent Psychiatric Clinics of North America 2005, | 4:429-5।, viii.

8. Yach D, Hawkes C, Gould CL, Hofman KJ: The global burden of chronic diseases: overcoming impediments to prevention and control. JAMA 2004, 291:2616-2622.

9. Taylor AL, Bettcher DW: WHO Framework Convention on Tobacco Control: a global "good" for public health. Bulletin of the World Health Organization 2000, 78:920-929.

10. Chaloupka FJ, Nair R: International issues in the supply of tobacco: recent changes and implications for alcohol. Addiction 2000, 95 Suppl 4:S477-89.

1I. Wilson N, Thomson G: The epidemiology of international terrorism involving fatal outcomes in developed countries (1994-2003). European Journal of Epidemiology 2005, 20:375-38I.

12. Wilson N, Thomson G: Deaths from international terrorism compared to road crash deaths in OECD countries. Injury Prevention 2005, I I:332-333.

13. Murray CJL, Lopez AD: The global burden of disease. Annex table I. State or territories included in the Global Burden of Disease Study, by demographic region. Geneva, Switzerland, World Health Organization; 1996.

14. Peto R, Lopez AD, Boreham J, Thun M, Heath C: Mortality from smoking in developed countries 1950-2000 (2nd edition). Oxford, Oxford University Press; 2003.

15. Ezzati M, Lopez AD: Measuring the accumulated hazards of smoking: global and regional estimates for 2000. Tobacco Control 2003, I 2:79-85.

16. Arnold JL, Ortenwall P, Birnbaum ML, Sundnes KO, Aggrawal A, Anantharaman V, AI Musleh AW, Asai Y, Burkle FMJ, Chung JM, CruzVega F, Debacker M, Della Corte F, Delooz H, Dickinson G, Hodgetts T, Holliman CJ, MacFarlane C, Rodoplu U, Stok E, Tsai MC: A proposed universal medical and public health definition of terrorism. Prehospital and Disaster Medicine 2003, 1 8:47-52.

17. Whitaker B: The definition of terrorism. Guardian 200I, 7 May: [http://www.guardian.co.uk/elsewhere/journalist/story/ $0,7792,487098,00 . \mathrm{html}]$. Accessed 17 August 2005

18. United Nations Office of Drugs and Crime: Definitions of terrorism. 2004 [http://www.unodc.org/unodc/ terrorism definitions.html]. Vienna, United Nations Office of Drugs and Crime Accessed 17 August 2005

19. Peto R, Lopez AD, Boreham J, Thun M, Heath Cl: Mortality from tobacco in developed countries: indirect estimation from national vital statistics. Lancet 1992, 339: I268-1278.

20. Doll R, Peto R, Boreham J, Sutherland I: Mortality in relation to smoking: 50 years' observations on male British doctors. $B M J$ 2004, 328: 1519 .

21. Centers for Disease Control and Prevention: Annual smokingattributable mortality, years of potential life lost, and productivity losses--United States, 1997-200 I. Morbidity and Mortality Weekly Report 2005, 54:625-628.

22. Shatenstein S, Chapman S: The banality of tobacco deaths. Tobacco Control 2002, I I: I-2.

23. Lerner JS, Gonzalez RM, Small DA, Fischhoff B: Effects of fear and anger on perceived risks of terrorism: a national field experiment. Psychological Science 2003, I 4: I44-I50.

24. Slovic P: Public perception of risk. Journal of Environmental Health 1997, 59:22-24.

25. Slovic P: Perception of risk. In The Earthscan Reader in risk and modern society Edited by: Lofstedt R and L. Frewer L. London, Earthscan; 1998.

26. Jamieson $\mathrm{P}$, Romer $\mathrm{D}$ : What do young people think they know about the risks of smoking? In Smoking: Risk, perception and policy Edited by: Slovic P. Thousand Oaks Ca, Sage Publications; 200 I.
27. Vaughan P: Perceiving risks. In The World Health Report 2002 Reducing Risks, Promoting Healthy Life Edited by: Campanini B. Geneva, World Health Organization; 2002.

28. Russell C: Living can be hazardous to your health: how the news media cover cancer risks. Journal of the National Cancer Institute Monographs 1999:167-I70.

29. Harrabin R, Coote A, Allen J: Health in the news: Risk, reporting and media influence. London, Kings Fund Publications; 2003.

30. Berke PR: Reducing natural hazard risks through state growth management. Journal of the American Planning Association 1998, 64:76-87.

31. Moser SC, Dilling L: Making climate hot. Environment 2004, 46:32-48.

32. Jha $P$, Chaloupka FJ: The economics of global tobacco control. Bmj 2000, 321:358-361.

33. Peck R, Chaloupka FJ, Jha P, Lightwood J: A welfare analysis of tobacco use. In Tobacco Control in Developing Countries Edited by: Jha P and Chaloupka F]. Oxford, Oxford University Press; 1999.

34. Saloojee $Y$, Dagli E: Tobacco industry tactics for resisting public policy on health. Bulletin of the World Health Organization 2000, 78:902-910.

35. Muggli ME, Hurt RD, Repace J: The tobacco industry's political efforts to derail the EPA report on ETS. American Journal of Preventive Medicine 2004, 26:167-I77.

36. Liberman J, Clough J: Corporations that kill: The criminal liability of tobacco manufacturers. Criminal Law Journal 2002, 26:223-237.

37. Hopkins DP, Briss PA, Ricard C), Husten CG, Carande-Kulis VG, Fielding JE, Alao MO, McKenna JW, Sharp DJ, Harris JR, Woollery TA, Harris KW: Reviews of evidence regarding interventions to reduce tobacco use and exposure to environmental tobacco smoke. American Journal of Preventive Medicine 200I, 20:16-66

38. Ranson MK, Jha P, Chaloupka FJ, Nguyen SN: Global and regional estimates of the effectiveness and cost-effectiveness of price increases and other tobacco control policies. Nicotine and Tobacco Research 2002, 4:3।I-319.

39. VicHealth Centre for Tobacco Control: Tobacco control: A blue chip investment in public health. Melbourne, VicHealth Centre for Tobacco Control; 2003.

40. Collins $\mathrm{D}$, Lapsley $\mathrm{H}$ : Counting the costs of tobacco and the benefits of reducing smoking prevalence in New South Wales. Sydney, New South Wales Department of Health; 2005.

4I. Richardson L: Buying biosafety--is the price right? New England Journal of Medicine 2004, 350:212I-2123.

42. Elworthy S, Rogers P: The 'War on Terrorism': 12 month audit and future strategy options. 2002 [http://www.oxfordresearch group.org.uk/publications/briefings/waronterrorism.pdf]. Oxford, Oxford Research Group Accessed 4 December 2005

43. Gaddis JL: Grand Strategy in the Second Term. Foreign Affairs 2005, 84:2-15.

44. Frey BS: Dealing With Terrorism: Stick or Carrot? Northampton, Edward Elgar; 2004.

45. Klarevas L: Political realism: A culprit for the $9 / 1 \mathrm{I}$ attacks. Harvard International Review 2004, 26:18-23.

46. Falkenrath RA: Problems of Preparedness. International Security 200I, 25: $147-186$.

47. Florig HK: Public health. Is safe mail worth the price? Science 2002, 295: | 467-| 468.

48. Fowler RA, Sanders GD, Bravata DM, Nouri B, Gastwirth JM, Peterson D, Broker AG, Garber AM, Owens DK: Cost-effectiveness of defending against bioterrorism: a comparison of vaccination and antibiotic prophylaxis against anthrax. Annals of Internal Medicine 2005, I 42:60I-6I0.

49. Wipfli H, Stillman F, Tamplin S, da Costa e Silva VL, Yach D, Samet ] Achieving the Framework Convention on Tobacco Control's potential by investing in national capacity. Tobacco Control 2004, 13:433-437.

50. Beaglehole R, Yach D: Globalisation and the prevention and control of non-communicable disease: the neglected chronic diseases of adults. Lancet 2003, 362:903-908.

5I. Perry W]: Preparing for the Next Attack. Foreign Affairs 200I, 80:31.

52. Drozdiak W: The North Atlantic Drift. Foreign Affairs 2005, 84:88-98. 